\title{
IJARAH DALAM KEUANGAN ISLAM
}

\section{Choirunnisak, Azka Amalia Jihad}

Perbankan Syariah STEBIS IGM Palembang,

Syariah dan Hukum UIN Ar- Raniry Banda Aceh

azka.jihad@ar-raniry.ac.id, Choirunnisak-umar@stebisigm.ac.id

\begin{tabular}{ll}
\hline & Abstrak \\
\hline Article History & This study aims to find out how \\
Received: 16 Juni 2020 & Ijarah in Islamic finance. This \\
Revised: 18 Juni 2020 & research is a type of library \\
Accepted: 19 Juni 2020 & research (libraty research) which \\
\hline Keywords: & focuses on qualitative data \\
Ijarah, Keuangan Islam & management with data analysis \\
& methods using descriptive-analysis \\
& method. The results of this study \\
& are: In Banking, two types of Ijarah. \\
& The first ijarah is done in cash \\
& between the bank as a renter and the \\
& one who rents out services. The \\
& second ijarah is made in \\
& installments between banks as \\
& tenants to customers. The bank also \\
& takes advantage of this ijarah \\
& transaction. Islamic banks that \\
& operate ijarah products do leasing, \\
& both in the form of operating leases \\
& or financial leases. But in general, \\
more Islamic banks use ijarah \\
vomiting tamlik bit (IMBT) because \\
is simpler in terms of \\
bookkeeping. Ijarah contract \\
development is also known as ijarah \\
muntia bi at-tamlik (IMBT).
\end{tabular}

\section{Pendahuluan}

Akad ijarah dalam konteks fiqh mu'amalah merupakan bagian dari al-'uquud al-musammah. Sama halnya dengan jual beli, syirkah, dan yang lainnya akad ijarah adalah akad yang telah disebutkan dalam al-Quran dan telah diatur oleh Allah. Secara khusus dalam 
syariat Islam akad ijarah sangat di perhatikan, baik pada sisi karakter maupun pada sisi akad. Karena akad ijarah berbeda dengan akad jual beli. Pada akad ijarah bersifat temporal dan pada akad jaul beli mempunyai sifat permanen karena adanya pemindahan pada kepemilikan barang. (al-Zuhaili, 2011: 385)

Ijarah menurut hukum Islam adalah suatu kontrak (akad) pengalihan hak pemanfaatan terhadap suatu kepemilikan aset selama periode waktu tertentu sesuai dengan kesepakatan antara pihak yang berkontrak dengan pemberian sejumlah imbalan tertentu. Akad ijarah juga mencakup pada pengupahan atau penyewaan tenaga kerja dan kontrak kerja untuk siapa pun dengan balasan imbalan (upah). Menurut para fuqaha kontemporer dan ahli keuangan Islami, ijarah merupakan model pembiayaan Islami yang memiliki potensi yang besar sebagai alternatif terhadap bunga bagi sistem keuangan Islam yang sedang berkembang.(Ayub, 2009: 427)

Ijarah diperbolehkan berdasarkan kitab suci al-Quran, sunnah Nabi Muhammad SAW, dan ijma' para fuqaha dan ulama. Berdasarkan pandangan Imam Syafi'i dan banyak fuqaha lain, dua ayat kitab suci al-Quran, karena sifat dasar umumnya, mengacu pada legalitas ijarah. Pemberian barang untuk dipergunakan adalah jenis umum aktivias bisnis yang disahkan oleh syariah karena merupakan sarana yang mudah bagi orang untuk mendapatkan hak memanfaatkan aset yang tidak mereka miliki, karena tidak semua orang mampu memiliki aset nyata tersebut untuk dapat dimanfaakan. Penelitian Umi Khusnul Khotimah 2017, Analisi Hukum Islam Terhadap Pelaksanaan Akad Ijarah Pada Pembiayaan multijasa multijasa di pt. bprs pnm binama Semarang. Jenis penelitian ini adalah penelitian lapangan (field research). Adapun dalam pengumpulan data, penulis menggunakan metode observasi, wawancara dan dokumentasi. Sumber data dalam penelitian ini ada dua, yaitu: data primer dan data sekunder. Setelah data terkumpul, langkah selanjutnya adalah menganalisis data kemudian mengambil kesimpulan dengan menggunakan metode deskriptif kualitatif. Hasil penelitian ini menunjukkan bahwa, pelaksanaan akad ijarah pada pembiayaan multijasa di PT. BPRS PNM BINAMA Semarangmenurut hukum Islam belum sah, dapat dilihat dari rukun dan syarat ijarah belum terpenuhi secara sempurna. Akad ijarah yang terjadi dalam pembiayaan ini selain mendahului akad wakalah, objek 
dalam transaksi ijarah tidak dapat dinilai ketika akad dimana menurut hukum Islam transaksi semacam ini tidak diperbolehkan.

Penelitian Rizki Mukarroh 2017 implementasi akad ijarah jasa layanan tukang kurir Purwosari dalam prespektif kemaslahatan. Dalam penelitian ini menggunakan jenis penelitian lapangan dengan pendekatan deskriftif kualitatif. Sumber data yang di gunakan adalah data primer dan data skunder dengan metode pengumpulan data menggunakan wawancara dan studi dokumen. Kemudian, dalam analisis data dilakukan melalui tahap tahap yaitu pemeriksaan data, klarifikasi, verifikasi, analisis, dan pembuatan kesimpulan. Hasil penelitian, dalam pelaksanaan tukang kurir Purwosari telah sesuai dengan perjanjian dan dan tercapai maslaha karena tidak ada yang merasa di rugikan.

Peneliti membahas secara terperinci mengenai perspektif teoritis kontrak (akad) ijarah, aplikasi akad ijarah modern pada lembaga keuangan Islam, konsep dan aplikasi ijarah Muntahia bi atTamlik pada Bank Islam, dan juga ringkasan pedoman untuk Bankir Islami mengenai akad ijarah. Perkembangam akad ijarah juga dikenal dengan istilah ijarah muntahia bi at-tamlik (IMBT). Akad ijarah yang dipraktikkan pada lembaga keuangan Islam dengan prinsip pembiayaan secara modern dapat berupa financial lease atau sewa beli, operating lease dan lain sebagainya.

\section{Metode Penelitian}

Penelitian ini merupakan penelitian jenis pustaka (libraty research) yang menitik beratkan pada pengelolaan data secara kualitatif dengan metode analisis data menggunakan metode deskriptif-analisis. Penelitian ini bertujuan untuk menggambarkan atau membeberkan apa yang terjadi sekarang (Arianto, 2002: 9) dan mengeksplorasi penomena-penomena yang tidak dapat dikuantifikasikan. (Djam'an dkk, 2013:23)Selain itu, deskriptif penting karena merupakan metode analisis data yang berfungsi untuk menjelaskan suatu pikiran (fakta) sehingga dapat diterima secara rasional . 


\section{Pembahasan}

\section{PerspektifTeoritis Akad Ijarah Pengertian Akad Ijarah}

Al-ijarah berasal dari kata al-ajru yang arti menurut bahasanya al- 'iwadh, yang arti dalam bahasa Indonesia ialah ganti dan upah. Secara istilah ijarah berarti akad sewa-menyewa untuk mengambil manfaat dari objek sewa dengan pemberian imbalan (upah) tertentu yang disepakati. (Sahrani ,dkk, 2011:168.)Menurut para ahli fiqh ijarah adalah pemindahan hak pemanfaat suatau barang bukan pemindahan hak milik. Dan si pemilik barang akan mendapatkan biaya sewa atau biaya penggunaan suatu barang. (Ayub, 2009:427428). Pembiaya ijarah menurut Fatwa DSN No. 09/DSNMUI/IV/2000 ijarah merupakan akad pemindahan hak guna pada periode tertentu dengan pembayaran biaya sewa dan bukan pemindahan hak milik.(Fatwa DSN No. 09/DSN-MUI/IV/2000 tentang Pembiayaan Ijarah, 1) Berdasarkan definisi tersebut,ada 5 yang terkandung pada ijarah

a) Ijarah merupan salah satu dari sebuah kontrak

b) pengalihan hak pemanfaatan

c) merupakan barang/ harta tertentu

d) dalam jangka waktu tertentu

e) Dengan imbalan berupa uang sewa yang telah disetujui

\section{Perbedaan antara Ijarah dengan Bai' (Jual Beli)}

Ijarah, dalam hal tertentu, serupa dengan kontrak (akad) jual beli karena dalam kedua kasus tersebut ada sesuatu yang dialihkan ke orang lain untuk ganjaran yang berharga. Oleh karena itu, manfaat dan ganjaran dalam ijarah harus diketahui secara komprehensif untuk menghindari konflik. Akan tetapi akad ijarah atau sewa menyewa berbeda dengan jual beli. Dalam akad jual beli, jika akad sudah disepakati, maka akan terjadi pemindahan kepemilikan dari penjual kepada pembeli. Sedangkan pada kontrak ijarah, setelah akad disepakati, belum terjadi pemindahan kepemilikan, karena penyewa hanyalah mengambil manfaat dari barang yang disewakan. Jadi, yang berpindah adalah hak untuk memanfaatkan dari barang yang disewa bukan hak kepemilikan.(Ayub, 2009: 429)

Pada ijarah kepemilikan badan properti yang digunakan tetap menjadi milik badan properti, penyewa hanya memanfaatkan 
properti. Sementara pada jual beli kepemilikan dialihkan pada pembeli. Jika pihak penyewa menjadi milik properti badani dengan suatu cara, seperti hadiah atau warisan, ijarah tidak akan berlaku lagi.

Praktiknya pada lembaga keuangan Islam, keduanya juga adalah produk pembiayaan berbasis utang. Bank memberi nasabah pembiayaan dan membebankan margin laba, bank mendapatkan kepemilikan atas aset mewakili nasabah. Angsuran dibayarkan seiring waktu untuk menutupi biaya aset dan memberikan margin laba bagi bank. Praktiknya pada lembagan keuangan, misalnya bank syariah, terdapat perbedaan antara ijarah dengan akad BBA (Bai' Bithaman Ajil) atau murabahah. Pada akad ijarah, bank terus menjadi pemilik sepanjang jangka waktu ijarah, sementara nasabah mendapatkan manfaat berupa penggunaan aset. Karena itu, risiko yang terkait kepemilikan aset tetap ada di tangan bank. Pada BBA-murabahah misalnya, nasabah adalah pemilik aset. Jumlah angsuran ditetapkan dalam hal BBA-murabahah, misalnya saat tingkat suku bunga patokan naik atau turun, jumlah angsuran tidak bisa diubah. Akan tetapi, dalam kasus ijarah, jumlah angsuran bisa disesuaikan tergantung pada perkiraan kondisi ekonomi sepanjang jumlah angsuran ditentukan dan pasti pada awal kontrak. (Abdullah,dkk, 2012:217)

\section{Landasan Hukum Ijarah}

Dasar hukum ijarah terdapat dalam al-Quran, hadits Rasulullah SAW, dan juga berdasarkan kepada ijma' ulama. Salah satu ayat alQuran yang membicarakan mengenai kontrak ijarah adalah QS. AlQashash; 26, yang artinya sebagai berikut: "salah seorang dari kedua wanita itu berkata: "Ya bapakku ambillah ia sebagai orang yang bekerja (pada kita), karena Sesungguhnya orang yang paling baik yang kamu ambil untuk bekerja (pada kita) ialah orang yang kuat lagi dapat dipercaya".

Ayat al-Quran lainnya yang menjadi dasar hukum kontrak ijarah adalah QS. At-Thalaq; 6, dan QS. A-Kahfi; 77. Hadits Rasulullah SAW yang diriwayatkan dari Ibnu Abbas ra, ia berkata: "Sesugguhnya Rasulullah SAW. pernah berbekam dan memberikan upah kepada pembekamnya". (HR.Bukhari, Muslim, dan Ahmad). (al-Albani, 2007: 55) 
Hadits Nabi yang lain yang driwayatkan oleh Ibnu Majah ra, disebutkan: "Berilah upah para pekerja sebelum kering keringat mereka”. (HR. Abu Ya'la, Ibn Majah, Tabrani dan Tirmidzi). (Rivai ,dkk, 2014:18) Ulama Islam sepakat untuk membolehkan akad ijarah karena merupakan sarana yang dapat memberikan kemashlahatan bagi umat. Akad ijarah memberikan kemudahan bagi orang yang tidak mampu memiliki barang untuk dapat memanfaatkan aset tersebut dari orang yang mampu memilikinya.

Secara yuridis dasar hukum transaksi pembiayaan berdasarkan akad Ijarah antara lain adalah Pasal 19 ayat 1 huruf $\mathrm{f}$ dan ayat (2) huruf $f$ serta Pasal 21 huruf $b$ angka 4 UU No. 21 Tahun 2008 tentang Perbankan Syariah. Fatwa DSN No. 9/DSN-MUI/IV/2000 tentang Pembiayaan Ijarah, dan PBI No. 7/6/PBI/2005 tentang Transparansi Informasi Produk Bank dan Penggunaan Data Pribadi Nasabah beserta ketentuan perubahannya dan PBI No.9/19/PBI/2007 tentang Pelaksanaan Prinsip Syariah dalam Kegiatan Penghimpunan Dana dan Penyaluran Dana serta Pelayanan Jasa Bank Syariah berikut perubahannya dengan PBI No. 10/16/PBI/2008.

\section{Peraturan Hukum Umum Ijarah Rukun dan Syarat Ijarah} berikut:

Rukun-rukun dan syarat-syarat akad ijarah adalah sebagai

a. Mu'jir dan musta'jir, yatu orang yang melakukan akad sewamenyewa atau upah menguah. Mu’jir adalah orang yang menyewakan dan akan memperoleh imbalan, sedangkan musta'jir adalah penyewa. Disyaratkan bahwa kedua orang ini haruslah baligh, berakal, dan mampu melakukan tasharuf (pengendalian harta).

b. Shighat atau ijab kabul antara mu'jir dan musta'jir yang berarti menyatakan kerelaan keduanya melakukan akad ijarah. Apabila salah seorang diantara mereka terpaksa melakukan akad ini, maka akad ijarahnya tidak sah.

c. Ujrah, disyaratkan harus jelas dan tertentu jumlahnya, sesuatu yang memiliki nilai ekonomi dan diketahui oleh kedua belah pihak baik dalam sewa-menyewa maupun dalam upahmengupah.

d. Objek ijarah atau barang yang disewakan, merupakan barang yang dihalalkan oleh syara' dan dapat diambil manfaatnya. 
Berdasarkan standar akuntansi dan audit untuk lembaga keuangan Islam (AAOIFI), terdapat tiga syarat pokok yang harus ada dalam penerapan akad ijarah, yaitu: ( Kettel, 2008:114)

1. Kesepakatan termasuk di dalamnya penawaran dari izin dari kedua belah pihak.

2. Dua pihak yang melakukan kesepakatan (pihak yang berakad) yaitu; pihak yang menyewakan (pihak yang memiliki aset untuk disewakan), dan pihak penyewa (pihak yang memperoleh pemanfaatan dari barang yang disewakan).

3. Objek akad ijarah, harus jelas dari segi kuantitas dan barang tersebut adalah barang yang bermanfaat.

\section{Pelaksanaan Kontrak (Akad) Ijarah}

Pelaksanaan kontrak (akad) ijarah sangat tergantung pada sifat dasar asetyang disewakan.Jika objek (aset yang disewakan) sudah ada, seperti keberadaan rumah yang dapat ditinggali, Maka akad ijarah bisa dilakukan pada saat yang di telah tentukan atau pada waktu selanjutnya. Hal ini diperbolehkan karena hak pemanfaatan atas objek sewa sudah jelas bagi pihak-pihak yang dapat menentukan uang sewa dengan mengingat manfaatnya. Pelaksanaan penyewaan yang akan datang ini juga dibolehkan karena alasan kepemilikan objek sewa tetap berada pada pihak yang menyewakan, yang bertanggung jawab terhadap risiko kerusakan aset.

Pelaksanaan akad ijarah pada kontrak IjarahMausufah bil Zimmah, yaitu penyewaan terhadap aset yang ditentukan terlebih dahulu. Sehingga kehancuran atau kerusakan unit tertentu dari aset tidak mengakhiri kontrak (akad). Maka pelaksanaan kontrak ijarah dapat dilaksanakan pada seketika itu maupun di masa yang akan datang. (http://www.zaharuddin.net/.) Namun, pada kasus sub-lease atau menyewakan kembali aset sewaan, ijarah hanya bisa dilaksanakan jika adanya kepemilikan dari asset yang akan di gunakan atau di manfaatkan, Penyewaan yang termasuk jenis ini adalah penyewaan pada bank syariah. Berdasarkan kebutuhan nasabah, pihak bank syariah dapat membeli aset dari pasar atau dalam kasus tertentu bank syariah membeli aset dari nasabah itu sendiri untuk kemudian menyewakan kembali kepada nasabah tersebut. Hal ini disebut kasus "penjualan dan penyewaan kembali" dan kontrak 
(akad) penjualan/pembelian harus mendahului akad penyewaan. (Ayub,2009:433-434)

\section{Hal-hal yang Terkait dengan Penentuan Uang Sewa}

Berdasarkan pada kesepakatan kedua belah pihak yang melakukan akad ijarah,Biaya uang sewa bisa di tentukan sesuai dengan biaya yang telah di keluarkan pihak pemberi sewa. Dan ini tidak bertentangan dengan ketentuan dalam Islam. Setelah perjanjian disepakati, pihak yang menyewakan tidak dapat menaikkan uang sewa secara sepihak dan perjanjian apapun yang memiliki efek pada hal sebaliknya akan batal.

Jika uang sewa telah ditentukan, bisa terdapat beberapa uang yang berbeda untuk fase-fase yang berbeda pula yang didasarkan pada tolok ukur yang telah disetujui selama periode penyewaan. Hal ini dapat terjadi pada kontrak penyewaan dalam jangka waktu yang lama. Penyewaan dalam waktu yang lama, maka dapat disetujui bahwa uang sewa akan dinaikkan setelah periode waktu tertentu, seperti satu tahun atau lainnya. Ulama kontemporer juga memperbolehkan penyewaan jangka panjang dengan mengaitkan uang sewanya dengan tarif atau tolok ukur variabel yang terdefinisikan secara jelas atau meningkatkan uang sewa secara periodik berdasarkan proporsi yang telah ditetapkan secara bersamasama (misalnya 5\% setiap tahun) jika persyaratan syariah lainnya untuk penyewaan telah dipenuhi secara tepat.

Tingkat inflasi, tingkat pajak, atau indeks harga apapun, tingkat pertumbuhan atau tingkat pengembalian yang terdefinisikan secara jelas dalam sektor riil perekonomian dapat digunakan sebagai tolok ukur. Seperti mengaitkan biaya sewa dengan LIBOR (London Interbank Offer Ratel Tingkat suku Bunga Pinjaman Antabank). Hal ini dibolehkan karena untuk membantu menghindari perselisihan atau ketidakadilan dengan salah satu pihak karena kemungkinan adanya fluktuasi dalam struktur harga pasar dan sifat mengikat dari kontrak (akad) ijarah. (Ayub,2009:434-435.)

Jadi, penggunaan kadar atau tingkat tertentu hanya sebagai tolok ukur (uang sewa mengambang) tidak menjadikan kontraknya tidak sah, asalkan jumlah uang sewa dari periode kontrak (akad) ijarah pertama ditentukan. Tentunya, akan lebih baik menggunakan tolok ukur selain tolok ukur tingkat suku bunga sehingga transaksi Islami benar-benar terbedakan dari transaksi non-Islami, tanpa 
adanya kemiripan dengan tingkat suku bunga apapun. Guna mengindari gharar bagi kedua belah pihak, ulama sepakat menyarankan hubungan antara uang sewa dan tingkat referensinya harus memiliki batas atas. Misalnya, dapat ditentukan bahwa uang sewa tidak akan naik atau turun lebih besar dari $5 \%$.

\section{Sub-Penyewaan oleh Musta'jir}

Prinsipnya, sub-penyewaan diperbolehkan. Dengan ketentuan sudah di setujui oleh pihak yang menyewakan (mu'jir). Dalam perjanjian sewa ini dapat di tetapkan.Jika uang sewa di ambil subpenyewaan sebanding sengan dengan uang yang di bayarkan kepada mu'jir pertama yang memberi sewa, maka empat mazhab dalam Islam memperbolehkan.Saat terdapat perbedaan pembayaran sewa yang lebih tinggi di bandingkan pada penyewa awal maka ulama berbeda pendapat. Syafi'I dan hambali memperbolehkan.

Menurut Abu Hanafi musta'jir tidak boleh mendapat keuntungan dari penyewaan akhir pada sub-penyewaan, dan uang kelebihannya harus di peruntukkan pada dana sosial. Terkecuali musta'jir telah mengembangkan properti dengan menambah sesuatu pada objek sewa, atau menyewakannya dalam valuta yang berbeda dengan penyewaan pertama maka ia boleh menetapkan uang sewa yang lebih tinggi dan dapat menikmati kelebihan tersebut dari penyewa akhir.

Pendapat yang lebih dapat diterima oleh mayoritas ulama kontemporer adalah pendapat pertama, yaitu aset sewa dapat disewakan kembali tanpa menghiraukan besarnya uang sewa. Hal yang tidak diperbolehkan untuk dilakukan adalah musta'jir berpartisipasi dengan orang lain dalam menyewakan kembali objek sewa dan membagi uang sewa yang diterima dari penyewa akhir tanpa mengalihkan bagian kepemilikannya.(Ayub, 2009:437)

\section{Agunan/ Jaminan dalam Ijarah}

Kontrak (akad) ijarah diperbolehkan adanya jaminan angunan yang disyaratkan oleh pihak yang menyewakan kepada pihak penyewa. Penyerahan aset sewa kepada penyewa pada dasarnya merupakan bentuk kepercayaan kepada musta'jir dan ia berkewajiban melindungi aset tersebut dari segala kerusakan dan kebinasaan. Pada Fatwa DSN MUI No.9/IV/2000 Mengenai pembiayaan ijarah wajib 
mengsyaratkan adanya agunan pada pembiayaan. Bank Syariah wajib melakukan penilaian dengan baik dan seksama, baik penilaian agunan dan nasabah sesuai pasal 23 UU Perbankan Syariah. (Wangsawidjaja,2012: 214)

Pada pasal 2 UU Perbankan Syraiah, perbankan syaraiah wajib menilai dan menghitung anggunan, sehingga jika di kemudihan terjadi sebuah risiko maka perbankan tidak mengalami kerugian.(Pasa 23 ayat (1) dan (2) UU No. 21 Tahun 2008 tentang Perbankan Syariah, 16)

Objek sewa adalah barang yang menjadi agunan, di dalam prakteknya barang yang disewa nasabah bukanlah menjadi milik nasabah. Dan pihak Perbank Syariah menyediakan barang yangdi sewakan. Maksudnya adalah bahwa bank syariah tidak perlu memiliki objek sewa. Oleh karena itu, apabila objek sewa tersebut merupakan milik pihak ketiga dan bukan milik Negara/Pemda maka objek sewa tersebut dimungkinkan menjadi agunan dalam pembiayaan ijarah atau jaminan pihak ketiga. (Wangsawidjaja, 2012:214)

\section{Kewajiban Masing-masing Pihak}

Menyangkut kewajiban para pihak dalam kontrak ijarah,Pihak yang menyewakan mempunyai kewajiban yang berasal dari kepemilikan aset. Dan pihak penyewa mempunyai kewajiban atas barang sewa. Misalnya dalam kasus penyewaan rumah, mu'jir berkewajiban terhadap pembayaran pajak terkait properti miliknya, sedangkan biaya berupa pajak air, tagihan listrik, dan semua biaya yang terkait dengan penggunaan rumah tersebut merupakan kewajiban musta'jir untuk menanggungnya.

Risiko terhadap properti yang disewakan akan tetap menjadi tanggungan $m u$ 'jir selama periode penyewaan yang disebabkan oleh faktor-faktor di luar kendali musta'jir.Musta'jir berkewajiban mengganti rugi kepada mu'jir atas kerusakan pada aset yang disebabkan oleh penyalahgunaan atau kelalaian dirinya sendiri. Properti yang secara bersamaan dimiliki oleh dua orang atau lebih dapat disewakan, mereka bertanggung jawab secara bersama terhadap risiko dan uang sewa akan dibagi diantara mereka berdasarkan proporsi kepemilikan masing-masing terhadap aset atau sesuai dengan kesepakatan bersama. 


\section{Implikasi, Penghapusanatau Perubahan kontrak (akad) Ijarah}

Ijarah adalah suatu akad yg mengikat. Artinya pada pelaksanaan akad tersebut tidak dapat dibatalkan secara sepihak karena ini akan merusak keseimbangan dan tidak bersifat Islami. Akad ijarah dapat berakhir jika kedua belah pihak yang berakad sepakat untuk mengakhirinya atau terdapat sebab-sebab yang dapat mengakhiri kontrak yaitu sebagai berikut:

- Akad ijarah dapat berakhir antara pihak yang melakukan akad, jika salah satunya meninggal dunia. Namun, ulama kontemporer sepakat bahwa pelaksanaan akad ijarah dapat diteruskan oleh ahli warisnya. Namun ahi waris juga dapat mengakhiri kontrak jika merasa tidak mampu membayar uang sewa.

- Terjadi kerusakan pada assetsewa, sehingga tidak bisa di manfaatkan, maka berakhirla akad ijarah

- Musta'jir dapat mengakhiri penyewaan jika pihak mu’jir melanggar salah satu ketetapan dalam perjanjian penyewaan. Jika terjadi yang demikian maka musta'jir berkewajiban untuk membayar uang sewa yang telah jatuh tempo saja bukan unag sewa periode selajutnya.

- Akad ijarah berakhir karena telah habis waktu jatuh tempo yang telah disepakati kecuali terdapat halangan sehingga ditetapkan batas waktu tertentu, maka ijarah berakhir sampai berakhir batas waktu tersebut. (al-Zuhaili, 2011:429-430)

\section{Kegagalan Pembayaran atas Uang Sewa Jatuh Tempo}

Praktik ijarah juga terdapat perilaku yang menyimpang dari pihak musta'jir yang memanfaatkan aset sewa sehingga menyebabkan kerugian bagi mu'jir juga kelalaiannya dalam membayar uang sewa. Guna menghindari hal ini maka ulama membolehkan diberlakukannya sejumlah dana sanksi yang harus dibayarkan oleh musta'jir dalam membayar uang sewa. Jumlah denda yang dikenakan kepada musta'jir dapat disesuaikan dengan berapa lama terjadi kegagalan dan di hitung berdasarkan persentase dasar tahuanan.

Adapun denda tersebut tidak dapat menjadi pemasukan atau pendapatan institusi keuangan, namun dana ini digunakan sebagai dana sosial. Berdasarkan ketetapan ini, maka bank syariah dapat menetapkan dalam klausul perjanjian untuk menarik kepemilikan dari 
aset sewa atau menuntut jaminan untuk mengganti haknya jika terjadi kegagalan pembayaran uang sewa dari pihak debitur.

\section{Penggunaan Ijarah Modern}

Penyewaan (leasing) merupakan salah satu bentuk pembiayaan yang menempati porsi yang cukup besar dalam pelayanan finansial di dunia. Leasing pada awalnya bukan merupakan mode pembiayaan, melainkan hanya sebuah aktivitas bisnis seperti penjualan. Namun, leasing berkembang menjadi salah satu bentuk pembiayaan di berbagai negara karena beberapa alasan seperti sebagai pengurang pajak, sehingga lembaga keuangan menyewakan beragam jenis aset dan perlengkapan kepada para nasabah. Dalam lembaga keuangan Islam, penyewaan adalah instrumen yang penting dengan potensi yang besar, tidak hanya dari sisi manfaat, melainkan dipandang investasi yang "memiliki sifat berbasiskan aset" dalam keuangan Islam. Kegiatan penyewaan (leasing), dari sudut Islam, diatur oleh peraturan yang ditentukan oleh Fiqh untuk transaksi Ijarah . (Ayub, 2009:441)

Hal-hal yang mempengaruhi besarnya proporsi penggunaan sewa (leasing) sebagai alternatif pembiayaan antara lain:

1. Penjual menggunakan sewa untuk meningkatkan penjualan dengan menyediakan pendanaan bagi pembeli.

2. Sewa merupakan cara termudah bagi perusahaan untuk mencukupi kekurangan asetnya

3. Sewa dapat menjadi sumber pendanaan di luar neraca laporan keuangan .(Subramanyam, 2010:176)

Lembaga keuangan bank/non-bank di hampir seluruh negara di dunia, seperti Jerman dan Jepang dan sebagainya menggunakan penyewaan sebagai mode bisnis. Bentuk penyewaan yang digunakan oleh institusi tersebut adalah financial lease, financing lease, dan operating lease.

\section{Financial Lease Atau Sewa-Beli}

Financial lease adalah bentuk penyewaan dengan periode cukup lama (biasanya keseluruhan usia manfaat dari aset yang disewakan). Financial lease memungkinkan pihak yang menyewakan melakukan amortisasi biaya aset dengan tingkat pengembalian pasar. Bank melakukan pembayaran aset kepada 
pemasok secara langsung maupun tidak langsung melalui pihak penyewa. Penentuan besarnya uang sewa dilakukan bank dengan menghitung total biaya pembelian aset dan menambahkan dengan besaran keuntungan yang diinginkan, yang disesuaikan dengan harga aset dan lama sewa. Besarnya angsuran ditentukan berdasarkan pembagian jumlah agregat yang telah diperhitungkan dengan jumlah bulan penyewaan aset. Risiko kepemilikan aset ditanggung oleh nasabah, sebagai penyewa aset, yang artinya pihak yang menyewakan tidak mempunyai kepentingan dengan aset tersebut pada saat terjadinya kontrak. (Subramanyam, 2010:442)

Hal ini menyebabkan Financial lease disebut dengan sewa beli karena penyewa dapat memiliki aset setelah masa sewa, bahkan dalam beberapa kasus aset dapat dimiliki sebelum habis masa sewa dengan membayar sejumlah biaya tambahan.

\section{Financing Lease atau Jaminan}

Jaminan dalam kerangka konvesional merupakan transaksi pembiayaan semata dan tidak lebih dari perjanjian jaminan untuk jumlah yang dibiayai kepada pihak penyewa. Jaminan melibatkan pengalihan efektif atas semua risiko dan manfaat yang terkait dengan kepemilikan pada pihak penyewa. (Subramanyam, 2010:442)

\section{Operating Lease}

Operating lease merupakan bentuk penyewaan berupa pengalihan manfaat aset kepada pihak penyewa, dengan hak milik masih berada di tangan pihak yang menyewakan (lessor), dengan imbalan berupa uang sewa. Operating lease biasanya digunakan untuk aset dengan biaya yang tinggi dan memiliki waktu produksi lama, seperti pesawat terbang, kapal laut dan sebagainya. Operating lease jarang digunakan oleh lembaga perbankan, dan terkadang digunakan oleh lembaga non-bank bila berkaitan dengan permesinan yang terspesialisasi. Hal ini menandakan bahwa lembaga keuangan non-bank, sebagai pihak yang menyewakan, harus menanggung risiko keuangan, resesi, atau permintaan yang menyusut.

\section{Penilaian Syariah terhadap Sewa Konvensional}

1. Di akhir kontrak penyewaan, kepemilikan aset yang disewakan dialihkan ke pihak penyewa, baik dengan tambahan biaya 
ataupun tanpa biaya tambahan. Khusus dalam sewa-beli, telah disetujui bersama pada awal kontrak Ijarah akan mencakup penjualan aset dan jumlah yang diterima secara periodik dari pihak penyewa mencakup biaya uang sewa dan biaya aset.

2. Pihak penyewa mulai mengenakan uang sewa saat ia memberikan dana ke pemasok aset, artinya ia menyewakan aset sebelum membelinya dan mendapatkan imbalan tanpa harus menanggung risiko kepemilikan. Berdasarkan prinsip Syariah, uang sewa harus dikenakan dari tanggal ketika pihak penyewa mendapat manfaat dari aset yang disewakan atau setelah penyerahan aset, bukan hari ketika dananya diberikan ke pihak penyewa atau harga yang telah dibayarkan ke pemasok.

3. Pihak yang menyewakan mengalihkan semua risiko ke pihak penyewa, khususnya ketika nilai residu aset juga ditetapkan pada awal kontrak. Menurut prinsip syariah, semua biaya yang timbul untuk memperbaiki kerusakan yang menghambat penggunaan aset menjadi tanggung jawab pihak yang menyewakan, sementara pihak penyewa bertanggung jawab atas biaya pemeliharaan dan berjalannya aset. Hal inilah yang menjadi perbedaan utama antara penyewaan konnvensional dan penyewaan Islami. Dalam Operating lease konvensional, semua biaya dan risiko merupakan tanggung jawab penyewa, semaentara dalam Operating lease Islami pihak yang menyewakan harus memikul tanggung jawb pemeliharaan dan risiko serta biaya pemilikan. (Subramanyam, 2010:443)

4. Ketika aset dibiayai dengan menggunakan suku bunga mengambang, pemilik aset biasanya akan mendapat risiko dari fluktuasi tingkat bunga lewat pembayaran sewa aset oleh penyewa. Hal ini umumnya terjadi pada leasing konvensional. Masalah ini bertentangan dengan konteks Islami, karena pada transaksi sewa-menyewa pemberi sewa menyediakan aset, bukan pendanaan, jadi return yang didapat berdasarkan bentuk aset bukan suku bunga. Sementara dalam ijarah, biaya dan waktu sewa harus disetujui di awal, melalui jadwal yang disetujui dan jumlah pembayaran yang mungkin tidak seragam.

5. Leasing konvensional umumnya memberikan penalti atas keterlambatan pembayaran sewa, dimana hal ini tidak diperbolehkan dalam sewa-menyewa Islam. Jika terjadi keterlambatan pembayaran dalam ijarah, maka pemberi sewa 
tidak dapat menerima tambahan dalam bentuk apapun. (Kettle, 2008: 114)

\section{Penggabungan Dua Kontrak (Akad)}

Ijarah dan jual-beli merupakan dua jenis kontrak yang berbeda, dalam kontrak jual beli kepemilikan aset dialihkan seketika meskipun pembelian dilakukan secara kredit, sementara dalam ijarah kepemilikan benda tetap pada pihak yang menyewakan. Pengalihan kepemilikan atas aset yang disewakan tidak dapat dilakukan dengan menjalankan kontrak jual-beli setelah waktu sewa selesai. Namun, dalam beberapa kasus, aset diakui menjadi milik pihak penyewa, dikarenakan pembayaran dilakukan penuh beserta uang sewa.

Untuk mengatasi hal ini, sejumlah ulama kontemporer merekomendasikan kepada pihak yang menyewakan untuk melakukan perjanjian terpisah untuk menjual aset yang disewakan pada saat berakhirnya penyewaan. Prinsipnya adalah janji sepihak untuk melangsungkan kontrak di suatu masa yang akan datang diperbolehkan, dimana si pembuat janji, misalnya bank, berkewajiban memenuhi janjinya, namun pihak yang dijanjikan tidak berkewajiban melaksanakan kontrak pembelian aktual. Selain itu, ulam juga menawarkan kepada pihak yang menyewakan untuk menghibahkan asetnya kepada pihak penyewa pada akhir periode sewa. Hal ini dikarenakan biasanya bank sebagai pihak yang menyewakan telah menutup kesuluruhan biaya atas aset tersebut dan sudah mendapat keuntungan dari margin keuntungan dari pihak penyewa.

\section{Ijarah Muntaha-Bi-Tamlik (Imbt)}

Ijarah Muntahiya Bit Tamlik (IMBT) adalah transaksi ijarah yang disertai dengan pilihan untuk memiliki barang yang disewa dengan ketentuan yang telah disepakati oleh kedua belah pihak pada akhir masa sewa. (Yaya, 2008: 252)

Pelaksanaan transaksi IMBT haruslah di dahului dengan pelaksanaan akad ijarah terlebih dahulu, sehingga pada akad IMBT berlaku semua rukun dan syarat transaksi ijarah. Akad perjanjian IMBT harus disepakati ketika akad ijarah ditandatangani, dan pemindahan kepemilikan hanya dapat dilakukan setelah masa ijarah selesai. Janji pemindahan kepemilikan barang yang disepakati di awal tidak bersifat mengikat, oleh karenanya akad pemindahan 
kepemilikan dilakukan setelah masa ijarahselesai. (fatwa dewan syari'ah nasional no: 27/dsn-mui/iv/2002) IMBT, meski memiliki kesamaan dengan model penyewaan konvensional, memiliki perbedaan dengan penyewaan konvensional antara lain:

1. Dalam sewa konvensional, tanggal sewa terhitung semenjak pihak penyewa memberikan uang kepada pihak yang menyewakan, dalam IMBT tanggal sewa dimulai semenjak penyerahan aset kepada pihak penyewa.

2. Dalam sewa konvensional, harga perolehan aset dapat dibayarkan oleh pemasok ataupun pihak penyewa langsung pada pemasok sehingga ia dapat memperoleh aset yang disewakan langsung dari pemasok. Hal ini hampir sama dengan konsep Islam, namun jika pembayaran dilakukan oleh pihak penyewa langsung maka harus ada perjanjian perwakilan sebagai tambahan dari perjanjian penyewaan. Hal ini dikarenakan jika asetnya hancur sebelum penyerahan ke pihak penyewa, kerugian ditanggung oleh pihak yang menunjuk wakil, bukan wakilnya.

3. Dalam sewa konvensional semua risiko ditanggung oleh pihak penyewa, sementara dalam IMBT risiko aset akan ditanggung oleh bank selama nasabahnya bertindak sebagai wakil pembelian aset terkait.

Pengawasan syariah pembiayaan IMBT dilakukan oleh Dewan Pengawas Syariah (DPS) dalam rangka menguji kesesuaian transaksi ijarah dan IMBT yang dilakukan bank dengan fatwa Dewan Syariah Nasional (DSN). Pengawasan tersebut antara lain:

1. Memastikan penyaluran dana berdasarkan prinsip ijarah tidak dipegunakan untuk kegiatan yang bertentangan dengan prinsip syariah

2. Memastikan bahwa akad pengalihan kepemilikan dalam IMBT dilakukan setelah akad ijarah selsesai, dan dalam akad ijarah, janji untuk pengalihan kepemilikan harus dilakukan pada saat berakhirnya akad ijarah

3. Meneliti pembiayaan berdasarkan prinsip ijarah untuk multijasa menggunakan perjanjian sebagaimana diatur dalam fatwa yang diatur tentang pembiayaan multijasa dan ketentuan lainnya antara lain ketentuan standar akad.

4. Memastikan besar ujrah dengan menggunakan akad ijarah telah disepakati di awal dan dinyatakan dalam bentuk nominal bukan dalam bentuk persentase. 
Skema Pembiayaan IMBT antara lain:

1. Pertama, nasabah mengajukan permohonan ijarah dengan mengisi formulir permohonan. Berbagai informasi yang diberikan selanjutnya deverifikasi kebenarannya dan dianalisis kelayakannya oleh bank syariah.

2. Kedua, sebagaimana difatwakan oleh DSN, bank selanjutnya menyediakan objek sewa yang akan digunakan nasabah.Bank dapat melakukan pembelian aset secara langsung, atau menunjuk wakil manapun untuk tujuan ini.

3. Ketiga, nasabah menggunakan barang atau jasa yang disewakan sebagaimana yang disepakati dalam kontrak.

4. Keempat, nasabah menyewa membayar fee sewa kepada bank syariah sesuai dengan kesepakatan akad sewa. Besaran uang sewa dihitung berdasarkan biaya perolehan aset yang harus dibayarkan oleh pihak yang menyewakan.

5. Kelima, pada transaksi IMBT, setelah masa ijarah selesai, bank sebagai pemilik barang dapat melakukan pengalihan hak milik kepada penyewa.

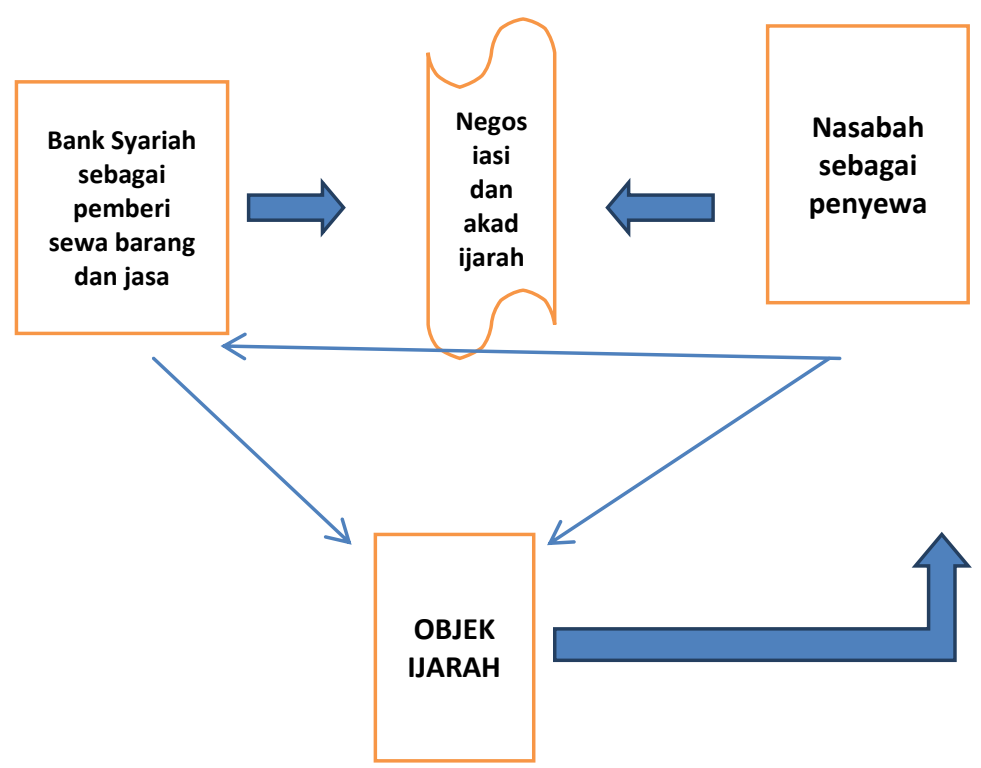




\section{Permasalahan Menyangkut Penggunaan Ijarah Modern}

Beban dari aset, berada di tangan pihak yang menyewakan atau pihak penyewa, merupakan salah satu permasalahan dalam Ijarah. Dalam ketentuan Syariah, kewajiban perbaikan barang, selain pemeliharaan umum, menjadi tanggung jawab pihak yang menyewakan. Klausul dalam kontrak yang mengartikan pengalihan biaya terkait kepemilikan, selain biaya operasional pada umumnya, kepada pihak penyewa tidaklah sah karena memperkaya pihak yang menyewakan secara tidak adil.

Permasalahan lain mucul karena kurangnya pengetahuan bank syariah mengenai prinsip Ijarah. Perjanjian Ijarah hanya dapat dilaksanakan setelah aset berada dalam kepemilikan pihak yang menyewakan. Jika terdapat keterlambatan dalam penyerahan aset ke pihak penyewa pada tanggal yang telah ditentukan maka tidak ada uang sewa yang dikenakan selama periode antara periode antara tanggal perjanjian dan tanggal penyerahan aktual.

Jika terjadi kerusakan pada tahap pemasokan, pihak penyewa (nasabah) yang bertindak sebagai wakil tidak bertanggungjawab atas aset.

Berkaitan dengan kasus kegagalan uang sewa oleh pihak penyewa karena sanksi yang dikenakan harus diberikan untuk sosial.

Persepsi umum yang mengatakan bahwa tingkat keuntungan bank yang tetap dari pembiayaan Ijarah adalah tidak benar. Hal ini dikarenakan bank syariah juga harus mengeluarkan semua biaya yang dipergunakan untuk memperoleh aset, termasuk biaya pembelian, pengiriman, sehingga bank memperhitungkan semua biaya tersebut ketika menetapkan besaran uang sewa. (fatwa dewan syari'ah nasional no: $27 / \mathrm{dsn}-\mathrm{mui} / \mathrm{iv} / 2002$ )

\section{Penyerahan Aset dan Pengonversian Penyewaan Menjadi Surat Berharga}

Prinsip Syariah membolehkan pihak penyewa untuk menjual aset yang disewakan kepada pihak ketiga, beserta dengan hak dan kewajibannya, dimana penjualan tersebut tetap sah dan Ijarah masih tetap berlangsung. Penjualan aset, mungkin diperlukan untuk aset dengan biaya perolehan tinggi seperti pesawat, kapal, alat industri, permesinan, jalan, jembatan, dan sebagainya. Namun, jika pada akhir masa sewa kepemilikannya tidak dialihkan, maka penggunaan sewa 
untuk transaksi moneter tidal dipebolehkan, karena uang (uang sewa) akan dijual untuk memperoleh uang.

Pihak baru yang membeli aset akan menikmati semua hak seperti yang didapat pihak penyewa, namun ia akan bertanggungjawab atas setiap kewajiban dibawah transaksi sewa. Hal ini menyebabkan Ijarah berpotensi untuk dikonversikan menjadi alat sekuritas (surat berharga) dan penciptaan pasar sekunder berbasisi Ijarah. Jika aset dijual kepada banyak investor maka pembelian proporsi aset oleh tiap investor dapat dibuktikan dengan sertifikat yang disebut "Sukuk Ijarah". Sertifikat tersebut akan mewakili kepemilikan prosporsional pemegangnya atas aset fisik yang terkait dengan kontrak Ijarah, dan pemegang akan menerima hak dan kewajibannya sebagai pemilik sejauh proporsi kepemilikannya. Sukuk Ijarah juga mempunyai risiko yang berkaitan dengan risiko pasar, yang berasal dari perubahan penetapan harga aset dan biaya pemeliharaan/takaful, serta kemampuan serta keinginan pihak penyewa untuk membayar cicilan uang muka. Berkenaan dengan hal ini, jumlah uang sewa yang ditetapkan dalam Sukuk Ijarah mencerminkan tingkat keuntungan maksimum yang tunduk terhadap pengurangan atas biaya tak terduga.(Ayub, 2009:457)

\section{Potensi Ijarah}

Penyewaan merupakan mode pembiayaan yang paling banyak digunakan oleh perusahaan dalam melaksanakan operasionalnya, sehingga hal ini membuka peluang pengembangan Ijarah untuk menjadi salah satu mode pembiayaan yang Islami. Ijarah adalah mode yang paling penting untuk pembiayaan kegiatan operasional bank Islam guna memenuhi kebutuhan ritel, korporat, dan publik, serta memiliki besar yang belum disadari. Ijarah digunakan langsung untuk pabrik dan pemesinan, otomotif, perumahan, barang konsumsi yang tahan lama, dan lain sebagainya. Pada sektor yang tidak langsung, seperti untuk penerbitan sukuk oleh sektor korporasi dan pemerintah. Ijarah bersifat kondusif bagi pembentukan investasi aset tetap jangka menengah dan panjang dalam perekonomian. Potensi yang dimiliki oleh Ijarah berkat beberapa karakteristik berikut:(Ayub, 2009:457) 
a. Pembayaran uang sewa Ijarah tidak terkait dngan periode pengambilan hak pemanfaatan oleh pihak penyewa, yakni dapat dilakukan sebelum awal periode, selama periode, atau setelah periode penyewaan, sesuai dengan kontrak atau keputusan kedua pihak.

b. Ijarah dapat digunakan untuk aset yang sudah ada atau bangunan dan bahkan untuk aset yang belum dibangun, selama aset tersebut digambarkan secara jelas dalam kontrak.

c. Tingkat uang sewa Ijarah dapat ditetapkan atau menggunakan sistem mengambang, asalan telah ditetapkan batas atas dan batas bawah uang sewa. Uang sewa harus ditetapkan dalam persayaratan yang jelas untuk periode baru di masa yang akan datang bisa tetap, meningkat atau menurun sesuai dengan tolok ukurnya.

d. Pemegang sukuk Ijarah secara bersama-sama mendapatkan perolehana atas aset, menanggung risiko harga dan biaya yang terkait dengan kepemilikan, serta mebagi uang sewa yang diterima dengan menyewakannya ke pengguna manapun.

Bank Islam menghadapi lima permasalahan dalam hal modus operasi bisnis penyewaan modern, yakni: (Ayub, 2009:454-455)

1. Permasalahan yang berkenaan dengan beban dari aset berada pada pihak penyewa atau yang menyewakan.

2. Permasalahan pada kurangnya pengetahuan bank Islam mengenai prinsip ijarah.

3. Jika terjadi kerusakan pada aset pada tahapan pemasokan, pihak penyewa (nasabah) yang bertindak sebagai wakil tidak bertanggung jawab atasnya hingga terbukti akan adanya kesalahan dari sisinya.

4. Permasalahan lainnya berkaitan dengan kenyataan bahwa hak pemanfaatan diperpanjang hingga ke suatu waktu di masa yang akan datang dan mungkin dapat beresiko serta tidak stabil, khususnya jika hak pemanfaatannya akan berkurang secara material di masa yang akan datang.

5. Permasalahan besar muncul dalam kasus kegagalan pembayaran uang sewa oleh pihak penyewa karena sanksi yang dikenakan harus diberikan untuk sosial. 


\section{Ringkasan Pedoman untuk Bankir Islami Mengenai Ijarah}

1) Menurut prinsip keuangan Islam, tidak ada perbedaan antara operating lease dan financing lease; jika keempat elemen mendasar yang berkaitan dengan pihak yang terikat kontrak (akad), subjek, ganjaran, dan periode ijarah telah diperhatikan dengan baik, ijarah dapat digunakan sebagai mode bisnis modern oleh institusi keuangan keuangan dalam bentuk Ijarah Muntahiabi-Tamlik. Faktor penentu dalam hal ini adalah risiko yang terkait dengan kepemilikan yang harus tetap berada pada pihak yang menyewakan dan penjualannya harus terpisah dari penyewaannya.

2) Penyewaan aset yang telah teridentifikasikan tidak dapat dimulai sebelum bank mengambil kepemilikan atas aset yang akan disewakan tersebut.Jika waktu kepemilikan aset yang akan disewakan tidak diketahui, keseluruhan pengaturannya akan bersifat sementara.

3) Pengaturan dua akad ke dalam satu akad dalam bentuk apapun tidak diperbolehkan oleh syari'ah.

4) Bank dapat mengembalikan kepemilikan kepada nasabah ataupun menjualnya di pasar terbuka ketika periode penyewaan berakhir.

5) Pihak yang menyewakan menanggung pengeluaran yang berkaitan dengan fisik dari aset, yakni Takaful, perbaikan kecelakaan, dan sebagainya, sementara pengeluaran operaional dalam pemanfaatan aset akan ditanggung oleh pihak penyewa.

Bank dapat secara bersama-sama memperoleh aset dengan nasabah yang hendak mendapatkan aset tersebut melalui penyewaan; selanjutnya bank dapat menyewakan bagiannya atas aset tersebut kepada nasabah. Uang sewa yang akan diterima oleh bank hanya akan sesuai dengan proporsi kepemilikannya dalam aset terkait. (Ayub, 2009:459)

\section{Pengurangan Risiko dalam kasus Ijarah}

Ada beberapa alat pengurang risiko untuk beberapa kasus dalam ijarah, antara lain: (Ayub, 2009:460)

1) Jika Bank membeli aset sesuai dengan permintaan nasabah, namun kemudian nasabah menolak menyewa aset tersebut, maka 
alat pengurang risiko yang dapat dilakukan adalah dengan janji mengikat untuk menyewakan harus diminta dari nasabah pada saat pemesanan/ pembelian aset oleh bank.

2) Nasabah mungkin gagal dalam pembayaran uang sewa yang jatuh tempo. Bank mungkin tidak dapat menutup kerugian atas investasinya sehingga aset kemudian ditarik kembali, tapi tidak mencakup kerugiannya. Maka alat pengurang risiko yang dapat dilakukan adalah upaya nasabah untuk meminta membayar sejumlah uang untuk sosial dalam kasus keterlambatan pembayaran uang sewa harus diminta ke nasabah. Jumlah uang ini akan diberikan ke rekening sosial.

3) Risiko aset dari pemeliharaan utama atau kehancuran, sehingga alat pengurang risikonya adalah dengan fasilitas Takaful.

4) Penghentian dini dari perjanjian penyewaan. Mengingat nilai pasar, bank dapat pula mengambil asetnya kembali dan menjualnya di pasar untuk mencairkan investasinya. Dalam kasus yang lebih berisiko, upaya pembelian aset pada jadwal harga yang telah ditetapkan dapat diminta dari nasabah.

5) Pihak penyewa bisa menggunakan aset tanpa berhati-hati sehingga menuntut bank menanggung pengeluaran pemeliharaan besar. Maka alat pengurang risiko yang dapat dilakukan adalah tanda kepercayaan harus diminta dari nasabah untuk mengikatnya untuk menggunakan aset sebagai walinya. Dapat pula disebutkan dalam tanda kepercayaan tersebut bahwa kerugian yang diakibatkan oleh kelalaian nasabah akan ditanggung oleh nasabahnya sendiri.

6) Risiko tingkat pengembalian karena adanya inflasi. Risiko ini dapat ditanggulangi dengan tingkat uang sewa mengambang yang dikaitkan dengan tolak ukur tertentu, yang diperbolehkan asalkan ada batas atas dan bawah tertentu.

7) Penjualan aset pada saat jatuh tempo-nasabah bisa membelinya atau tidak. Maka alat pengurang risiko yang dapat dilakukan adalah hanya aset yang dapat disewakan yang memiliki nilai jual kembali yang dapat bank jual di pasar. Kalau tidak, janji terpisah untuk membeli pada akhir periode penyewaan dapat diminta dari nasabah. 


\section{Perbandingan IMBT dengan produk penyewaan otomotif konvensional}

Ada beberapa hal yang membedakan antara Ijarah Muntahia Bi Tamlik (IMBT) dengan produk penyewaan otomotif konvensional, antara lain: (Ayub, 2009:461-462)

1) Pada penyewaan konvensional mengandung perjanjian jual beli dan dilarang oleh Islam sedangkan ijarah hanya kontrak sewa.

2) Pada penyewaan konvesional semua kerusakan dan kerugian di tanggung penyewa. Dalam Islam penyewa hanya meanggung beban terkait pemakaian dan semua yang berkaitan dengan kepemilikan akan di tanggung ileh pihak bank.

3) Biaya Asuransi tidak termasuk dalam kontrak (akad) penyewaan. Beban asuransi dari aset dibebankan pihak penyewa. Sedangkan dalam IMBT, Takaful harus menjadi tanggungan pihak yang menyewakan. Namun, pihak yang menyewakan bisa meningkatkan dengan kesepakatan pihak penyewa, uang sewanya guna menutup biaya takaful.

4) Pada kasus kehilangan atau kerusakan bila perusahaan asuransi tidak mengompensasi, maka nasabah tidak wajib membayar sisanya Sedangkan bank Islam menanggung risiko penyelesaian tuntutan Takaful;

5) Jika kendaraan yang disewakan dicuri atau hancur total, pihak perusahaan penyewaan konvensional akan tetap menuntut uang sewa hingga tuntutan asuransi benar benar selesai. Sedangkan di bawah sistem Islam, uang sewa adalah ganjaran untuk penggunaan aset yang disewakan, dan jika asetnya telah dicuri atau hancur, konsep penyewaan menjadi batal, dan bank Islam tidak dapat menggunakan uang sewa tersebut; dan

6) Dalam beberapa kebijakan penyewaan konvensioanal penyewa bisa memberhentikan penyewaan kapanpun. Pada ijarah penyewaan tidak bisa dihentikan secara sepihak.Dan dapat pula ditentukan dalam perjanjian bahwa jika pihak penyewa melanggar salah satu persyaratan dalam perjanjian, pihak yang menyewakan berhak menghentikan kontrak penyewaan secara sepihak.

7) Dalam kebanyakan financelease kontemporer, ada sejumlah Ada biaya denda yang harus dibayarkan jika ada keterlambatan, pembayaran uang denda sewa dan menjadi pendapatan bagi 
institusi, ini di haramkan dalam Islam.Pada ijarah jika ada keterlambatan pembayaaran maka akan di berikan pada dana sosial namun bank tidak dapat mengenakan keuntungan lagi.

8) Dibawah kontrak penyewaan,.nama pada kendaraan secara otomatis akan dialihkan kepada nama nasabah pada saat periode penyelesaian penyewean.Sedangkan pada ijarah, nasabah tidak berkewajiban membeli kendaraan tersebut. Ia dapat membeli aset tersebut melalui penjualan formal jika hal ini dianggap bermanfaat.

9) Pembayaran uang tunai pada uang muka, pembayaran uang tunai pada premi asuransi di tahun pertama, serta pengeluaran asuransi, biaya uang sewa pada bulan pertama, dan lain-lain. Simpan pinjam pada perbankan syariah dan dikembalikan jika waktu penyewaan selesai.

Dalam referensi yang lain dijelaskan bahwa ada beberapa perbedaan mendasar antara ijarah dengan sewa menyewa secara konvensional, antara lain sebagai berikut: (Kettel, 2008:97) pertama, Pembayaran sewa berdasarkan bunga, kedua, Denda bunga dengan default, ketiga, Masalah asuransi dan keempat pemeliharaan, Permasalahan landasan syari'ah. Di dalam referensi yang lain ditambahkan beberapa perbedaannya sebagai berikut:

1. Bank konvesional tidak melakukan sewa-beli.

2. Leasing konvensional diselenggarakan oleh Lembaga Keuangan Bukan Bank (LKBB) di bawah peraturan/ UU Departemen Keuangan.

3. Bank konvensional melakukan kredit biasa yang besarnya angsuran sama dengan cara sewa.

4. Manfaat bagi nasabah untuk melakukan transaksi sewa-beli adalah dalam bidang pembukuan nasabah, biaya sewa masuk dalam pos biaya, dan bukan angsuran hutang sehingga meringankan pajak. (Tim Pengembangan Perbankan Syariah, 2001:150)

\section{Simpulan}

Ijarahmerupakan akad sewa yang menjadi salah satu mode keuangan Islam yang telah banyak digunakan di lembaga keuangan Islam. Dalam hukum Islam, ijarah adalah pengalihan hak pemanfaatan untuk ganjaran berupa sewa dalam hal penyewaan aset 
atau barang dan upah dalam hal penyewaan orang.Praktek ijarah pada perbankan syariah tidak sama persis dengan ijarah pada buku fikih.

Pada buku fiqh ijarah hanya melibatkan dua pihak. Pada perbankan ijarah terdapat dua akad dan tiga pihak. Pertama ijarah secara tunai antara bank dan penyewa jasa. Kedua secara cicilan antara pihak bank sebagai penyewa kepada nasabah. Pihak Bank juga mengambil keuntungan terhadap transaksi ijarah ini.Bank syari'ah yang mengoperasikan produk ijarah melakukan leasing, baik dalam bentuk operating lease ataupun financial lease. Namun pada umumnya bank syari'ah lebih banyak yang menggunakan ijarah muntahia bit tamlik (IMBT) karena lebih sederhana dari sisi pembukuannya. Perkembangam akad ijarah juga dikenal dengan istilah ijarah muntahia bi at-tamlik (IMBT). 


\section{DAFTAR PUSTAKA}

Brian KetteL, 2008. Introduction to Islamic Banking and Finance. Printhause Northamton: United Kingdom.

Daud Vicary Abdullah dan Keon Chee, 2012. Buku Pintar Keuangan Syariah. Cara Mudah Memahami Prinsip, Praktik, Prospek, dan Keunggulan Keuangan Islam di Zaman Kita. Pnj. Satrio Wahono, Jakarta: Zaman.

Djam'an, Satori, dan Aan, Komariah, 2013. Metodologi Penelitian Kualitatif. Bandung: Alfabeta.

Fatwa Dewan Syari'ah Nasional no: 27/Dsn-Mui/iv/2002.

Fatwa Dsn no. 09/Dsn-Mui/iv/2000 Tentang Pembiayaan Ijarah.

Khotimah, Umi Khotimah. 2017. Analisis Hukum Islam Terhadap Pelaksanaan Akad Ijarah pada Pembiayaan Multijasa di PT BPRS PNM BINA Semarang. Skripsi Progam Ilmu Hukum Ekonomi Islam. Universitas Islam Negeri Walisongo Semarang.

Muhammad Ayub, 2009. Understanding Islamic Finance: A-Z Keuangan Syariah, Jakarta: Gramedia Pustaka Utama.

Muhammad Nashiruddin al-Albani, 2007. Ringkasan Shahih Bukhari. Jilid 3. Pnj. M. Faisal, dkk, Jakarta: Pustaka Azzam.

Mukarromah, Rizki. 2017. Implementasi akad ijarah jasa layanan tukang kurir purwosari dalam perseptif kemaslahatan. Skripsi Program Hukum Bisnis Islam. Universitas Islam Negri Mulana Malik Ibrahim Malang.

Rizal Yaya, dkk, 2014. Akuntansi Perbankan Syariah, Jakarta: Salemba Empat.

S, Arikunto, 2020. Prosedur Penelitian Suatu Pendekatan Praktek. Jakarta: Asdi Mahasatya. 
Sohari Sahrani dan Ru'fah Abdullah, 2011. Fikih Mu'amalah, Jakarta: Ghalia Indonesia.

Subramanyam, K.R, dan John J. Wild, 2010.Analisisi Laporan Keuangan, Jakarta: Salemba Empat.

Undang-Undang No. 21 Tahun 2008 tentang Perbankan Syariah

Wahbah al-Zuhaili, 2011. Al-Fiqh al-Islamî wa-Adillatuh. Hukum Transaksi Keuangan, Transaksi Jual-beli, Khiyar, Macammacam Akad Jual Beli, Akad Ijarah (Penyewaan). jilid 5. (Terj. Abdul Hayyie al-Kattani), Jakarta: Gema Insani.

Wangsawidjaja Z, 2012. Pembiayaan Bank Syariah, Jakarta: PT. Gramedia.

Veitzal Rivai, Abdul Hadi Sirat, dkk, 2014 Principle of Islamic Finance. (Dasar-dasar Keuangan Islam) Saatnya Hijrah ke Sistem Keuangan Islam yang telah Teruji Keampuhannya, Yogyakarta: BPFE.

\section{Sumber dari Website}

Ijarah di Bank Islam. Diakses pada tanggal 1 juni 2020 dari situs: http://www.zaharuddin.net/. 